\title{
MANAJEMEN RISIKO PADA BANDARA SOEKARNO HATTA BERBASIS ISO 31000
}

\author{
TERRY GEORGE ABISAY ${ }^{1}$ DAN NURHADI ${ }^{2}$ \\ ${ }^{1)}$ Departemen Supply Chain Management, PT Freeport Indonesia, Mile Post 38 Timika Papua \\ 2) Jurusan Teknik Mesin, Politeknik Negeri Malang \& Contract Consultant pada Departemen Quality Management Services \\ (QMS), PT Freeport Indonesia Papua \\ Jl. Soekarno Hatta No. 8, Malang
}

Laman: nurhadiabuzaka@gmail.com,terry.abisay@yahoo.com

\begin{abstract}
ABSTRAK
Bandara Soekarna Hatta sebagai perusahaan aviasi bertaraf internasional ternyata belum menerapkan sistem manajemen risiko berstandar internasional yang mengacu pada ISO 31000, sehingga berdampak pada munculnya potensi risiko negatif bagi keselamatan jiwa, lingkungan, harta benda dan reputasi perusahaan. Tujuan penelitian untuk melakukan penilaian risiko dan pengendalian risiko menggunakan sistem manajemen risiko dengan standar internasional. Penelitian manajemen risiko diarahkan pada dampak negatifyang ditimbulkan oleh suatu kejadian pada operasional bandar udara, khususnya Fasilitas Operasi dan. Tahapan proses manajemen risiko mengacu pada ISO 31000 meliputi identifikasi risiko, analisis risiko dan evaluasi risiko menggunakan tools penelitian fishbone dan Risk Breakdown Structure (RBS). Ekspektasi dampak dan kemungkinan kejadian dipetakan melalui risk matrix dari Federation Aviation Administration (FAA). Hasil penelitian menunjukkan bahwa pada bandara Soekarno Hatta terdapat 7 peristiwa risiko yang mempunyai potensi bahaya yaitu: pecahnya permukaan runway, kecelakaan pesawat saat take off/landing, terganggunya pelayanan navigasi dan komunikasi penerbangan, kecelakaan pesawat di area apron, gangguan keamanan di bandara, jetblast pesawat, dan lolosnya barang berbahaya ke dalam pesawat.
\end{abstract}

Kata Kunci: risiko, manajemen risiko, ISO 31000, fasilitas operasi dan teknik, risk matrix FAA

\begin{abstract}
Soekarna Hatta Airport as an international aviation company hasn't yet implemented an international standard risk management system based on ISO 31000, so it triggers the occurrence of negative impacts to the human, environment, property and company reputation. This research aims to conduct a risk assessment and control by using an international standard risk management system. Risk management research is focused on the negative impacts caused by an event of airport operations, particularly operations facility and machine. The Stages of the risk management process are based on ISO 31000 including risk identification, risk analysis, and risk evaluation using fishbone and Risk Breakdown Structure (RBS) tool. Impact Expectations and possible occurrence are mapped through the risk matrix which is defined by the Federation Aviation Administration (FAA). The results showed that there were 7 events at Soekarno Hatta airport that have potential risk, namely, outbreak of the runway track, plane accidence during take-off landing, disruption of flight navigation and communication services, accidence in the apron area, security disruption at the airport, aircraft jetblast, and entry of dangerous goods on board.
\end{abstract}

Keywords: risk, risk management, ISO 31000, operations and engineering facilities, risk matrix FAA

\section{PENDAHULUAN}

Risiko meliputi berbagai kehidupan dan bisa berdampak pada individu, bisnis maupun tingkatan sosial. Bidang Ilmu dan teknologi, kedokteran, transportasi, ekonomi dan lingkungan merupakan contoh bidang-bidang yang memungkinkan timbulnya berbagai jenis risiko, yang dapat menyebabkan kerusakan serius jika tidak dikontrol dan dikelola (Nota, 2010). Airmic (2010:4) menjelaskan risiko adalah 
efek dari ketidakpastian sasaran. Sedangkan efek ini merupakan penyimpangan dari pengharapan positif dan atau negatif. Sasaran meliputi berbagai aspek seperti finansial, kesehatan dan keselamatan, dan lingkungan. Dengan kala lain, risiko merupakan kemungkinan situasi atau keadaan yang dapat mengancam pencapaian tujuan serta sasaran sebuah organisasi atau individu.

Manajemen risiko merupakan proses iteratif yang terdiri dari langkah-langkah yang terdefinisi yang bertujuan mengidentifikasi dan mengelola risiko dengan baik. Penelitian manajemen risiko telah banyak dilakukan. Sepang (2013:288) menyatakan bahwa alternatif pengendalian risiko terjatuhnya pekerja konstruksi yaitu dengan inspeksi K3 harian untuk pemakaian Alat Pelindung Diri (APD), memperketat pengawasan manajemen terhadap pekerja yang tidak memakai alat pelindung diri, menyediakan dan melengkapi rambu-rambu keselamatan di proyek konstruksi jika tidak ada atau tidak lengkap. Labombang (2011:46) menyimpulkan bahwa dalam setiap proyek konstruksi sangat penting dilakukan manajemen risiko untuk menghindari kerugian atas biaya, mutu dan jadwal proyek. Yasa (2013:37) menjelaskan bahwa mitigasi risiko yang dapat dilakukan untuk menangani risiko dominan yakni dengan menghindari risiko, mengurangi risiko, dan memindahkan risiko. Mitigasi risiko dimulai dari aspek institusi, regulasi, pembiayaan, serta program teknis dan non teknis.

Manajemen risiko dalam suatu badan usaha (apapun bentuknya) akan sangat membantu dalam beberapa hal, yaitu: (1) Meramalkan dasar, besarnya serta frekuensi kemungkinan kerugian yang diderita bila terjadi suatu peristiwa yang tidak bisa diduga sebelumnya, (2) Menciptakan suatu dasar untuk mengurangi atau membatasi timbulnya suatu risiko, (3) Optimisasi biaya risiko dengan membandingkan biaya yang harus dikeluarkan bila dikelola melalui lembaga asuransi atau dikelola sendiri. Disamping itu bisa dipertimbangkan keuntungan dan kerugian bila risiko tidak dikelola, dan (4) Menyediakan suatu dasar pengambilan keputusan bagi untuk memperkirakan risiko yang mungkin timbul. Jadi manajemen risiko merupakan keputusan eksekutif yang bertujuan mengelola risikorisiko yang akan dihadapi oleh badan usaha, khususnya risiko murni-statis, di mana akibatnya selalu menimbulkan kerugian bagi badan usaha tersebut. (Harimurti, 2006: 112).

Manajemen risiko berstandar internasional mengacu pada ISO 31000. Standar ini menggambarkan kerangka kerja implementasi manajemen risiko yang dimulai dari identifikasi risiko, analisis risiko dan evaluasi risiko sebagaimana Gambar 1. Gambar 1 ini menjelaskan versi sederhana dari proses manajemen risiko ISO 31000. Tahaptahap kunci dalam proses direpresentasikan sebagai penilaian risiko dan penanganan risiko. Gambar ini juga menunjukkan bahwa proses manajemen risiko berlangsung dalam konteks risiko manajemen organisasi. (Airmic, 2010: 7)

Manajemen risiko pada bandar udara sangatlah penting. Setiap bandar udara adalah unik dan mempunyai karakteristik sendirisendiri terutama dalam hal operasional, fasilitas dan jumlah pergerakan pesawat udara, sehingga

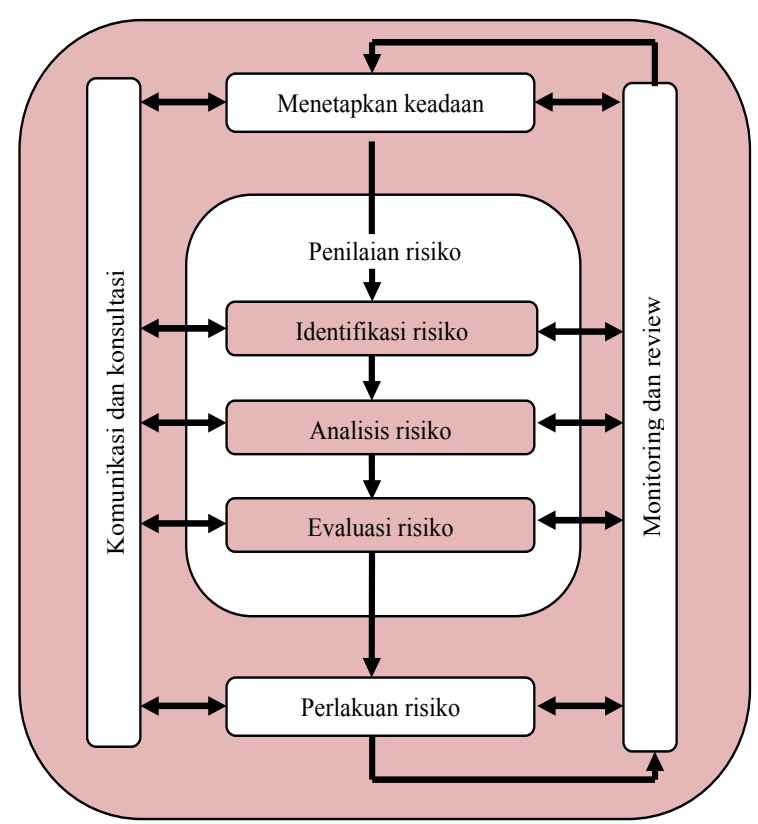

Gambar 1. Proses Manajemen Risiko Berbasis ISO 31000

(Sumber: Airmic, 2010: 9) 
pengembangan Sistem Manajemen Keselamatan terbentuk mengikuti karakteristik tersebut. Bandara Soekarno Hatta sebagai perusahaan aviasi bertaraf internasional terbesar di Indonesia, ternyata belum menerapkan sistem manajemen risiko yang mengacu pada ISO 31000. Oleh karena itu perlu dilakukan penelitian untuk menjelaskan bagaimana melakukan pemetaan, penilaian risiko dan perancangan sistem pengendalian untuk pencegahan dan penanggulangan risiko pada fasilitas Operasi dan Teknik di PT. Angkasa Pura II Bandara Soekarno Hatta dengan mengacu pada standar internasional. Penelitian bertujuan untuk melakukan penilaian risiko dan pengendalian risiko termasuk identifikasi risiko dan analisis bahaya pada fasilitas Operasi dan Teknik Bandara, agar dapat dilakukan pencegahan dan penanggulangan dampak risiko pada setiap fasilitas tersebut menggunakan sistem manajemen risiko dengan standar internasional. Dengan penelitian ini diperoleh manfaat berupa pemahaman yang baik tentang manajemen risiko, penilaian risiko dengan standar ISO 31000, pemetaan risiko ke dalam risk matrix standar FAA, perancangan sistem pencegahan dan pengendalian risiko.

\section{METODE}

Metode penelitian manajemen risiko dilakukan mengacu pada ISO 31000. Tahapannya dimulai dari identifikasi risiko, analisis risiko dan evaluasi risiko. Seluruh risiko yang teridentifikasi diperhitungkan dampaknya terkait dengan tujuan yang ingin dicapai perusahaan.

Identifikasi risiko bertujuan untuk membuat daftar risiko secara luas yang dapat memengaruhi pencapaian tujuan perusahaan. Metode identifikasi risiko yaitu wawancara dengan kepala bagian Corporate Risk Management (CRM) pusat dan asisten Facility Risk Management (FRM) yang dinilai mumpuni dalam memahami sumber risiko, area dampak, peristiwa, penyebab dan potensi akibatnya. Tahapannya yaitu: (1) pendataan seluruh peristiwa risiko negatif yang mungkin terjadi dengan penyebaran kuisioner, wawancara, studi literatur dan observasi lapangan, dan (2) pemetaan risiko dan pemilihan risiko yang terkait masalah operasi dan teknis. Data peristiwa, sumber, dan dampak risiko tersebut dikonfirmasi oleh koordinator CRM, kemudian dimasukan dalam daftar risiko (risk register).

Analisis risiko bertujuan untuk menilai risiko dari daftar risiko yang telah dikonfirmasi. Caranya dengan mengalikan besaran dampak risiko dengan kemungkinan kejadiannya, untuk menentukan kegawatan risiko. Input tahapan ini yaitu daftar risiko yang telah dikonfirmasi, sedangkan outputnya berupa daftar risiko baru. Evaluasi risiko bertujuan untuk memilih risiko yang paling potensial dari daftar risiko yang ada. Caranya dengan memetakan daftar risiko baru hasil analisis risiko kedalam FAA risk matrix. Pemetaan risiko dilakukan antara nilai dampak dan nilai kemungkinan kejadian dengan matriks risiko yang telah disediakan. Dari risiko yang dipetakan maka terlihat jenis-jenis risiko dari yang paling potensial atau berbahaya hingga yang biasa atau dapat ditoleransi. Input tahapan ini yaitu daftar risiko baru, sedangkan outputnya yaitu daftar risiko potensial.

Perancangan sistem pengendalian bertujuan untuk menyiapkan tindakan yang harus dikerjakan jika risiko tersebut belum/telah terjadi, sehingga tiap risiko memiliki tindak lanjut yang jelas dan juga untuk mengurangi kesalahan perusahaan. Metodenya dengan mencegah risiko yang mungkin terjadi dan menanggulangi risiko yang telah terjadi. Input tahapan ini yaitu daftar risiko potensial hasil dari pemetaan risiko. Setelah mendapatkan urutan prioritas risiko, maka dibuat agregasi risiko dengan warna merah, kuning dan hijau. Risiko pada zona merah akan ditindaklanjuti dengan merancang sistem pengendalian. Risiko dengan zona hijau dan kuning tidak dibuatkan sistem pengendalian karena dinilai masih bisa ditangani dengan SOP yang berlaku. Setelah zona masing-masing risiko diketahui, selanjutnya diurutkan berdasarkan Risk Priority Numbers $(R P N)$ terbesar hingga terkecil. Perancangan sistem pengendalian didasarkan pada agregat 
yang telah dibuat (bagian yang merah saja), karena bagian merah merupakan risiko yang harus segera ditanggapi.

Hasil perancangan diberikan kepada kepala CRM pusat untuk divalidasi (bersifat subjektif) apakah semua pengendalian yang ada telah masuk telah kedalam sistem, jika sudah valid maka dilanjutkan dengan registrasi sistem pengendalian yang bertujuan untuk mendokumentasikan dan menetapkan langkah pengendalian jika telah atau belum terjadi kejadian. Sistem pengendalian selanjutnya dianalisis tingkat hazard-nya pada masing-masing dinding pencegahan dan dinding penanggulangan yang dibuat yang selanjutnya dinilai secara subjektif oleh kepala FRM dan hasilnya diserahkan kepada kepala CRM.

\section{HASIL DAN PEMBAHASAN Identifikasi risiko}

Sebelum dilakukan identifikasi risiko melalui wawancara dengan narasumber, pertama kali dibuat Risk Breakdown Structure (RBS) berdasarkan unit-unit dibawah fasilitas
Operasi dan Teknik. Untuk mengetahui lebih dalam risiko pada unit-unit tersebut, dilakukan pengidentifikasian dengan bantuan tool fishbone (cause and effect diagram) sebagaimana Gambar 2.

Identifikasi dengan menggunakan bantuan tools RBS dan fishbone dapat dilakukan dengan baik jika digabung dengan pertanyaan-pertayaan yang tepat dan terstruktur. ISO 31000 mempunyai standar pertanyaan yang dapat digunakan dalam wawancara pengidentifikasian risiko, yaitu: (1) apa sumber dari risiko, (2) apakah efeknya bagi tujuan perusahaan, (3) apakah ada pengendalian yang dilakukan saat ini, (4) kapan, di mana, mengapa dan bagaimana risiko-risiko ini dapat terjadi, dan (5) apa yang menyebabkan pengendalian yang ada saat ini kurang efektif. Teknik identifikasi seperti ini dinilai tepat karena peneliti tidak mempunyai pengalaman dalam merumuskan daftar risiko.

Berdasarkan hasil wawancara dengan kepala bagian CRM pusat dan asisten FRM serta laporanlaporan safety audit teridentifikasi sebanyak 30

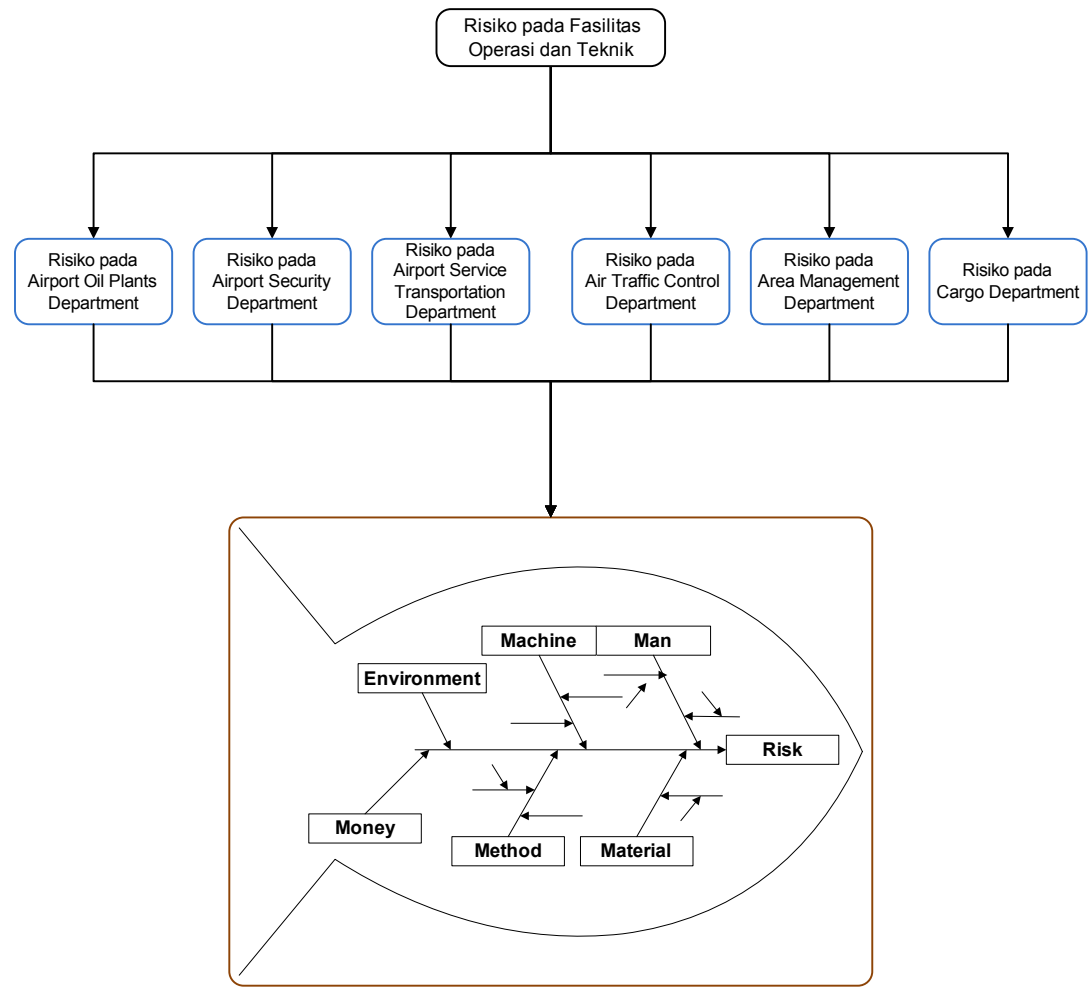

Gambar 2. RBS dan Fishbone

(Sumber: Abisay, 2011:67) 
peristiwa risiko yang berpotensi terjadi pada fasilitas operasi dan teknik PT. Angkasa Pura II Bandara Soekarno Hatta sebagaimana tabel 1.

\section{Analisis risiko}

Pada tahap ini daftar peristiwa risiko yang berhasil diidentifikasi selanjutnya dinilai secara subjektif isi. Penilaian dilakukan dengan

Tabel 1. Data peristiwa risiko dengan penyebab dan dampaknya

\begin{tabular}{|c|c|c|c|}
\hline No & $\begin{array}{c}\text { Nama Peristiwa } \\
\text { Risiko }\end{array}$ & Penyebab Risiko & Dampak Risiko \\
\hline \multirow[t]{4}{*}{1} & \multirow{4}{*}{$\begin{array}{l}\text { Terganggunya } \\
\text { pelayanan navigasi } \\
\text { dan komunikasi } \\
\text { penerbangan }\end{array}$} & $\begin{array}{l}\text { Fasilitas komunikasi melebihi idle } \\
\text { time }\end{array}$ & Terganggunya citra perusahaan \\
\hline & & Pengadaan sparepart lama & Komplain dari airline \\
\hline & & Kerusakan VSAT & \\
\hline & & Terdapat interference frequency & \\
\hline \multirow[t]{4}{*}{2} & \multirow[t]{4}{*}{$\begin{array}{l}\text { Remotesistem di } \\
\text { runway menyala }\end{array}$} & Fasilitas remote tidak berfungsi & $\begin{array}{l}\text { Terganggunya operasi } \\
\text { penerbangan }\end{array}$ \\
\hline & & Perawatan tidak sesuai SOP & \\
\hline & & $\begin{array}{l}\text { Persediaan suku cadang tidak } \\
\text { terpenuhi }\end{array}$ & \\
\hline & & Adanya obstacle di criticalarea & \\
\hline \multirow[t]{6}{*}{3} & \multirow[t]{6}{*}{ Radar down } & Kabinet transceiver tertutup & \\
\hline & & Perawatan rutin tidak terlaksana & Terganggunya citra perusahaan \\
\hline & & $\begin{array}{l}\text { Tidak adanya sensor elektronik } \\
\text { pada fan blower }\end{array}$ & \\
\hline & & Fan blower bekerja non stop & \\
\hline & & Suku cadang terbatas & \\
\hline & & $\begin{array}{l}\text { Gangguan peralatan pendukung } \\
\text { external }\end{array}$ & \\
\hline \multirow[t]{4}{*}{4} & \multirow{4}{*}{$\begin{array}{l}\text { Airfield Lighting } \\
\text { failure }\end{array}$} & Gangguan sistem kontrol di MPS & Terganggunya citra perusahaan \\
\hline & & Power suplai terputus & Komplain dari airline \\
\hline & & Kerusakan kabel & \\
\hline & & MMI Off & \\
\hline \multirow[t]{5}{*}{5} & \multirow{5}{*}{$\begin{array}{l}\text { Gagal switch lighting } \\
\text { pada ACC/APP } \\
\text { Gedung Tower }\end{array}$} & Catu daya rusak & Komplain dari airline \\
\hline & & $\begin{array}{l}\text { Kurang koordinasi pengoperasian } \\
\text { lampu dimmer }\end{array}$ & Menurunnya tingkat pelayanan \\
\hline & & Remote sistem rusak & \\
\hline & & Suku cadang rusak & \\
\hline & & Dimmer switch rusak & \\
\hline \multirow[t]{5}{*}{6} & \multirow[t]{5}{*}{$\begin{array}{l}\text { Kecelakaan pesawat di } \\
\text { area apron }\end{array}$} & $\begin{array}{l}\text { Miskomunikasi tentang pergerakan } \\
\text { pesawat maupun kendaraan di area } \\
\text { apron }\end{array}$ & $\begin{array}{l}\text { Hilangnya harta benda dan nyawa } \\
\text { manusia }\end{array}$ \\
\hline & & Jumlah petugas AMC terbatas & Komplain dari airline \\
\hline & & Marking dan sign kurang jelas & \\
\hline & & $\begin{array}{l}\text { Fasilitas groundhandling kurang } \\
\text { memadai }\end{array}$ & Terganggunya citra perusahaan \\
\hline & & Terbatasnya area Appron & \\
\hline
\end{tabular}


7 Keterlambatan Kurang jumlah personil penanganan kondisi Kesiapan peralatan kurang emergency di bandara memadai

Akses jalan kendaraan PK-PPK kurang memadai

8 Gangguan operasional Keterbatasan jumlah SDM yang dan pelayanan di terminal

9 Ketidaksiapan kendaraan PKP-PK

10 Jetblast pesawat

11 Sweeper mogok di TAXI WAY AREA

12 Crew reaction time> 25 detik berkompetensi

Pengembangan fasilitas bandara tidak seimbang dengan pertumbuhan pengguna jasa bandara

Ketidaksiapan personil

Kendaraan utama tidak siap

Ketidaksiapan prosedur

Terlalu dekat jarak gedung dengan apron

Melakukan run up sewaktu di apron

Menguji kekuatan power pesawat /open full thottle di apron

Usia kendaraan melebihi 20 tahun

Selang angin bocor

Filter solar macet

Posisi standby personil tersebar

Personil tidak sigap

Miskomunikasi

Personil kurang respons terhadap informasi

13 Penumpukan barang di kargo

Jumlah X- Ray hanya 1 unit

Kultur pengiriman barang cargolast minute

Kondisi X- Ray sudah tua

Luas gudang tidak memadai

14 Permukaan runway pecah

15 Timbulnya obstacle dalam kawasan keselamatan operasi penerbangan
Meningkatnya jumlah traffic

Menurunya permukaan air tanah

Dummy joint terlepas

Usia Teknis

Kurang optimal pengawasan dari petugas bandara

Hambatan koordinasi dengan institusi terkait

Sosialisasi KKOP kepada masyarakat kurang baik

KKOP belum didukung dengan peraturan daerah
Hilangnya harta benda dan nyawa manusia

Komplain dari airline

Terganggunya citra perusahaan

Menurunnya tingkat pelayanan

Terganggunya citra perusahaan

Hilangnya harta benda dan nyawa manusia

Terganggunya operasi penerbangan

Komplain dari airline

Menurunnya tingkat pelayanan

Menurunnya tingkat pelayanan

Terganggunya citra perusahaan

Hilangnya asset perusahaan

Menurunnya tingkat pelayanan

Hilangnya harta benda dan nyawa manusia

Runway closed

Terjadi kecelakaan pesawat 
16 Penertiban pass tidak terkontrol

17 Kebakaran di bandara

18 Proses pemeriksaan security kurang optimal

19 Lolosnya barang berbahaya ke dalam pesawat

20 Gangguan keamanan di bandara

21 Pemindahan bahan bakar ke skid tank terganggu

22 FOAM tender tidak optimal

23 Kecelakaan pesawat saat take off / landing
Terganggunya citra perusahaan

Pintu akses terlalu banyak

Personil security terbatas

Terdapat tumpahan bahan bakar kendaraan di apron

Rumput kering disisi bandara

Terdapat orang merokok disisi bandara

Jumlah SDM kurang memadai

Kinerja fasilitas security menurun

Pengaturan slot time tidak optimal

Kualitas layanan petugas kurang memadai

Teknologi X-ray tidak dapat

mendeteksi DG

Agent tidak memahami

penanganan DG

Jumlah SDM AVSEC bersertifikat

DG terbatas

Rusaknya pagar perimeter bandara

Jangkauan CCTV kurang memadai

SOP penanganan keamanan

kurang optimal dijalankan

Layout pengamanan yang terbaru

belum diketahui petugas

Kompetensi petugas kurang

memadai

Fasilitas pengamanan (X-ray,

WTMD, Explosive detector dll)

kurang memadai

Petugas kurang sigap

Nozzle bermasalah

Jumlah SDM terbatas

Gangguan pada bomb dan nozzle

Operasi penghisapan tidak bisa

Turret bomb tidak optimal

Operasi Andline/manual pump dari Terganggunya citra perusahaan samping off

Air \& fuel filterkotor

SDM kurang memadai

Switch start tidak optimal

FOD

Runway Incursion

Bird Strike

Layang-layang

Standing water
Hilangnya harta benda dan nyawa manusia

Rusaknya fasilitas bandara

Terganggunya citra perusahaan

Terganggunya citra perusahaan

Terjadi antrian penumpang

Hilangnya harta benda dan nyawa manusia

Komplain dari airline

Rusaknya fasilitas bandara

Lolosnya barang berbahaya

Menurunnya tingkat pelayanan

Menurunnya tingkat pelayanan

Hilangnya harta benda dan nyawa manusia

Terganggunya citra perusahaan 
24 Gagal catu daya listrik Sumber pasokan listrik PLN

terbatas dan sering terjadi

pemadaman

Gagal otonomi battery

Sambaran petir pada peralatan

Gagal proteksi

Sistem jaringan yang dimiliki sudah

memerlukan perawatan

25 Kekurangan jumlah pegawai

26 Hilangnya dokumen autentik perusahaan

27 Minimnya pemeliharaan bangunan

28 Wing tip clearance tidak terkendali

Perubahan struktur organisasi

Sebagian karyawan memiliki usia pensiun

Peta kebutuhan karyawan belum dilaksanakan secara optimal

Pola recruitment belum seimbang dengan formasi

Sarana penyimpanan data kurang optimal

Sistem kearsipan belum optimal

Pembatasan akses dokumentasi perusahaan belum optimal

Cuaca tidak menentu pemeliharaan

Desain parking stand

Perkembangan tipe pesawat
Hilangnya asset perusahaan

Kurangnya optimalnya kinerja staff Terganggunya citra perusahaan

Jumlah parking stand terbatas

Jumlah pesawat semakin

bertambah

29 Kepadatan penumpang Fasilitas check in counter terbatas di terminal

Permintaan airline pada saat golden

time

Personil security terbatas

Peralatan security kurang

30 Sistem aplikasi belum optimal

Terganggunya citra perusahaan

Terganggunya citra perusahaan

Penanganan fasilitas FIS di BSH kurang optimal
Menurunnya tingkat pelayanan

Hasil kerja tidak optimal

Hilangnya asset perusahaan

Tidak adanya pembelian aplikasi baru yang lebih baik

Adanya pengembangan sistem

(Sumber: Abisay, 2011: 71-77)

penyebaran kuisioner untuk mendapatkan jawaban subjektif dari para responsden yang merupakan pakar yang telah berpengalaman dalam bidang manajemen safety audit dan risiko operasi dan teknik. Responsden berjumlah 10 orang, berasal dari CRM pusat. Kuisioner dibagi menjadi 2 bagian, yaitu kemungkinan kejadian dan dampak. Penilaian menggunakan skala 1-5 sebagaimana yang telah menjadi rule of thumb metode FAA.

Kuisioner kemudian diuji validitas dan reliabilitasnya dengan menggunakan bantuan 
software SPSS 19. Uji validitas bertujuan mengetahui seberapa tepat kuisioner mengukur pernyataan-pernyataan yang terkait dengan kemungkinan kejadian dan dampak pada masingmasing peristiwa risiko. Sebelum melakukan uji validitas terlebih dahulu dilakukan uji kenormalan dengan metode kolmogorov-smirnov dengan SPSS 19. Hasil uji menunjukkan bahwa data tidak berdistribusi normal, sehingga uji validitas menggunakan statistik non parametrik yaitu korelasi Rank Spearman. Dari hasil uji validitas didapat seluruh pernyataan dalam kuisioner telah valid, sehingga dapat dilanjutkan ke uji reliabilitas. $\mathrm{n}$ totalnya

Uji reliabilitas bertujuan mengetahui sejauh mana hasil penilaian kuisioner dapat dipercaya. Jika penilaian dilakukan berulang menghasilkan hasil yang relatif sama maka kuisioner memiliki tingkat reliabilitas yang baik Uji ini dilakukan dengan menghitung nilai alpha cronbach's. Jika

Tabel 2. Perhitungan Statistik Kemungkinan Kejadian

\begin{tabular}{|c|c|c|c|c|c|c|c|}
\hline \multirow{2}{*}{$\begin{array}{c}\text { Nomor } \\
\text { Peristiwa risiko }\end{array}$} & \multicolumn{7}{|c|}{ Kemungkinan Kejadian } \\
\hline & $\begin{array}{c}\text { Geo } \\
\text { Mean }\end{array}$ & Median & Modus & ST Dev & Maximum & Minimum & $\begin{array}{c}\text { Geo Mean } \\
\text { Dibulatkan }\end{array}$ \\
\hline 1 & 3.3 & 3 & 3 & 0.4830 & 4 & 3 & 3 \\
\hline 2 & 1.8 & 2 & 2 & 0.7379 & 3 & 1 & 2 \\
\hline 3 & 2.0 & 2 & 2 & 0.7379 & 3 & 1 & 2 \\
\hline 4 & 2.4 & 2 & 2 & 0.5164 & 3 & 2 & 2 \\
\hline 5 & 2.2 & 2 & 2 & 0.4216 & 3 & 2 & 2 \\
\hline 6 & 2.7 & 3 & 3 & 0.4830 & 3 & 2 & 3 \\
\hline 7 & 2.6 & 3.0 & 3 & 0.5164 & 3 & 2 & 3 \\
\hline 8 & 3.1 & 3 & 3 & 0.5676 & 4 & 2 & 3 \\
\hline 9 & 2.4 & 2 & 2 & 0.5164 & 3 & 2 & 2 \\
\hline 10 & 2.4 & 2 & 2 & 0.5164 & 3 & 2 & 2 \\
\hline 11 & 2.4 & 2 & 2 & 0.5164 & 3 & 2 & 2 \\
\hline 12 & 1.8 & 2 & 2 & 0.5676 & 3 & 1 & 2 \\
\hline 13 & 2.7 & 3 & 3 & 0.4830 & 3 & 2 & 3 \\
\hline 14 & 3.5 & 4 & 3 & 0.6992 & 5 & 3 & 4 \\
\hline 15 & 2.4 & 2 & 2 & 0.5164 & 3 & 2 & 2 \\
\hline 16 & 5.0 & 5 & 5 & 0.0000 & 5 & 5 & 5 \\
\hline 17 & 2.4 & 2 & 2 & 0.5164 & 3 & 2 & 2 \\
\hline 18 & 3.4 & 3 & 3 & 0.5164 & 4 & 3 & 3 \\
\hline 19 & 1.9 & 2 & 2 & 0.6667 & 3 & 1 & 2 \\
\hline 20 & 4.4 & 4 & 4 & 0.5164 & 5 & 4 & 4 \\
\hline 21 & 2.0 & 2 & 2 & 0.7379 & 3 & 1 & 2 \\
\hline 22 & 1.4 & 2 & 1 & 0.5270 & 2 & 1 & 1 \\
\hline 23 & 4.4 & 4.0 & 4 & 0.5164 & 5 & 4 & 4 \\
\hline 24 & 4.4 & 4 & 4 & 0.5164 & 5 & 4 & 4 \\
\hline 25 & 2.0 & 2 & 2 & 0.5676 & 3 & 1 & 2 \\
\hline
\end{tabular}




\begin{tabular}{llllllll}
26 & 1.2 & 1 & 1 & 0.4830 & 2 & 1 & 1 \\
27 & 2.4 & 2 & 2 & 0.5164 & 3 & 2 & 2 \\
28 & 3.4 & 3 & 3 & 0.5164 & 4 & 3 & 3 \\
29 & 3.6 & 4 & 4 & 0.5164 & 4 & 3 & 4 \\
30 & 3.4 & 3 & 3 & 0.5164 & 4 & 3 & 3 \\
\hline
\end{tabular}

Tabel 3. Perhitungan Statistik Dampak

\begin{tabular}{|c|c|c|c|c|c|c|c|}
\hline \multirow{2}{*}{$\begin{array}{c}\text { Nomor Peristiwa } \\
\text { risiko }\end{array}$} & \multicolumn{7}{|c|}{ Dampak } \\
\hline & $\begin{array}{c}\text { Geo } \\
\text { Mean }\end{array}$ & Median & Modus & $\begin{array}{l}\text { ST } \\
\text { Dev }\end{array}$ & Maximum & Minimum & $\begin{array}{c}\text { Geo Mean } \\
\text { Dibulatkan }\end{array}$ \\
\hline 1 & 3.6 & 4 & 4 & 0.6749 & 5 & 3 & 4 \\
\hline 2 & 3.1 & 3 & 3 & 0.5676 & 4 & 2 & 3 \\
\hline 3 & 2.7 & 3 & 3 & 0.7888 & 4 & 2 & 3 \\
\hline 4 & 4.4 & 4 & 4 & 0.5164 & 5 & 4 & 4 \\
\hline 5 & 2.4 & 3 & 3 & 0.5270 & 3 & 2 & 2 \\
\hline 6 & 4.4 & 4 & 4 & 0.5164 & 5 & 4 & 4 \\
\hline 7 & 3.4 & 3.0 & 3 & 0.5164 & 4 & 3 & 3 \\
\hline 8 & 3.4 & 3 & 3 & 0.5164 & 4 & 3 & 3 \\
\hline 9 & 3.4 & 3 & 3 & 0.5164 & 4 & 3 & 3 \\
\hline 10 & 4.6 & 5 & 5 & 0.5164 & 5 & 4 & 5 \\
\hline 11 & 2.8 & 3 & 3 & 0.7379 & 4 & 2 & 3 \\
\hline 12 & 3.4 & 3 & 3 & 0.5164 & 4 & 3 & 3 \\
\hline 13 & 1.5 & 2 & 2 & 0.5164 & 2 & 1 & 2 \\
\hline 14 & 4.4 & 4 & 4 & 0.5164 & 5 & 4 & 4 \\
\hline 15 & 2.7 & 3 & 3 & 0.4830 & 3 & 2 & 3 \\
\hline 16 & 1.8 & 2 & 2 & 0.5676 & 3 & 1 & 2 \\
\hline 17 & 3.9 & 4 & 4 & 0.5676 & 5 & 3 & 4 \\
\hline 18 & 2.4 & 2 & 2 & 0.5164 & 3 & 2 & 2 \\
\hline 19 & 4.6 & 5 & 5 & 0.5164 & 5 & 4 & 5 \\
\hline 20 & 2.7 & 3 & 3 & 0.6325 & 4 & 2 & 3 \\
\hline 21 & 3.0 & 3 & 3 & 0.7379 & 4 & 2 & 3 \\
\hline 22 & 1.5 & 2 & 2 & 0.5164 & 2 & 1 & 2 \\
\hline 23 & 4.4 & 4.0 & 4 & 0.5164 & 5 & 4 & 4 \\
\hline 24 & 1.6 & 2 & 2 & 0.6749 & 3 & 1 & 2 \\
\hline 25 & 2.7 & 3 & 3 & 0.4830 & 3 & 2 & 3 \\
\hline 26 & 3.9 & 4 & 4 & 0.6667 & 5 & 3 & 4 \\
\hline 27 & 1.6 & 2 & 2 & 0.4830 & 2 & 1 & 2 \\
\hline 28 & 2.7 & 3 & 3 & 0.4830 & 3 & 2 & 3 \\
\hline 29 & 1.9 & 2 & 2 & 0.4714 & 3 & 1 & 2 \\
\hline 30 & 1.8 & 2 & 2 & 0.7379 & 3 & 1 & 2 \\
\hline
\end{tabular}


Tabel 4. Skala Kemungkinan Kejadian dan Dampak

\begin{tabular}{|c|c|c|c|c|c|}
\hline \multicolumn{3}{|c|}{ Likelihood/Kemungkinan Kejadian } & \multicolumn{3}{|c|}{ Severity/Dampak } \\
\hline Frequent & 5 & Sering & Catastrophic & 5 & Bencana Besar \\
\hline Probable & 4 & Mungkin & Hazardous & 4 & Berbahaya \\
\hline Remote & 3 & Sedikit/kemungkinan kecil & Major & 3 & Besar \\
\hline Extremely Remote & 2 & $\begin{array}{l}\text { Kemungkinan sangat } \\
\text { sedikit }\end{array}$ & Minor & 2 & Kecil \\
\hline $\begin{array}{l}\text { Extremely } \\
\text { Improbable }\end{array}$ & 1 & Sangat tidak mungkin & No Safety Effect & 1 & $\begin{array}{l}\text { Tidak Ada Pengaruh } \\
\text { Serius }\end{array}$ \\
\hline
\end{tabular}

(Sumber: Abisay, 2011:82)

Tabel 5. Risk matrix FAA

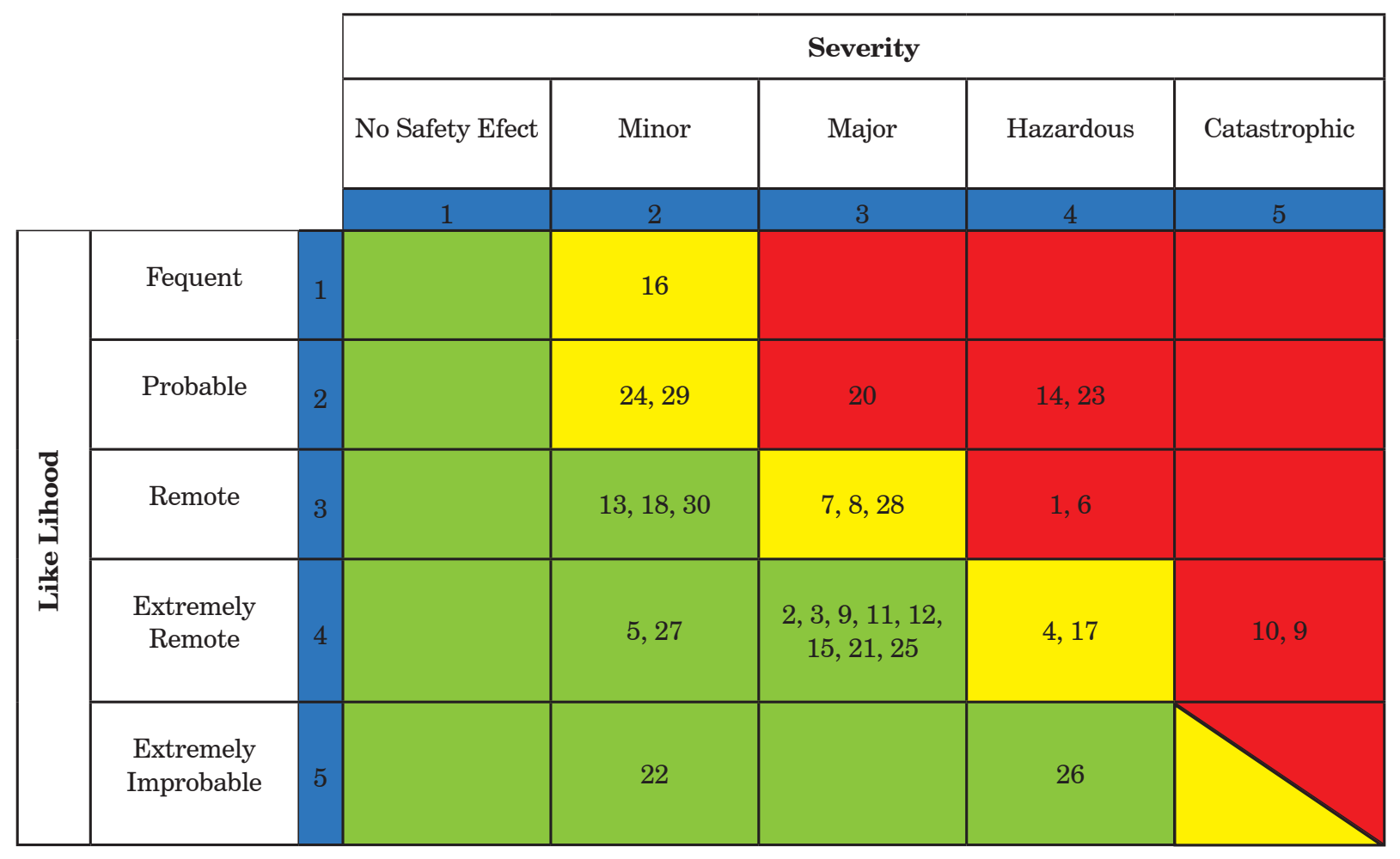

Tabel 6. RPN untuk Peristiwa Risiko dalam Zona Merah

\begin{tabular}{llrrr}
\hline No & \multicolumn{1}{c}{ Nama Peristiwa Risiko } & KK$^{*}$ & D $^{*}$ & RPN \\
\hline 14 & Permukaan runway pecah & 4 & 4 & 16 \\
23 & Kecelakaan pesawat saat take off/landing & 4 & 4 & 16 \\
1 & Terganggunya pelayanan navigasi dan komunikasi penerbangan & 3 & 4 & 12 \\
6 & Kecelakaan pesawat di area apron & 3 & 4 & 12 \\
20 & Gangguan keamanan di bandara & 4 & 3 & 12 \\
10 & Jetblast pesawat & 2 & 5 & 10 \\
19 & Lolosnya barang berbahaya ke dalam pesawat & 2 & 5 & 10 \\
\hline
\end{tabular}

*KK = Kemungkinan Kejadian

$* \mathrm{D}=$ Dampak 
nilai alpha cronbach's diatas 0,7 maka kuisioner dinyatakan reliabel. Dengan menggunakan bantuan software SPSS 19 diperoleh nilai alpha cronbach's untuk kemungkinan kejadian adalah 0,982 dan dampak adalah 0,981. Karena kedua nilai tersebut diatas 0,7 maka disimpulkan bahwa kuisioner reliabel dan tidak ada peristiwa risiko yang harus dibuang, baik untuk kemungkinan kejadian maupun dampak.

Pada analisis statistik deskriptif dilakukan perhitungan mean, median, modus, standar deviasi, nilai tertinggi dan nilai terendah dengan software microsoft excel 2007. Nilai atribut ini didapat dari subjektivitas melalui proses pengisian kuisioner dengan hasil perhitungan sebagaimana Tabel 2 dan 3.

\section{Penilaian Risiko}

Penilaian risiko dilakukan berdasarkan risk matrix 5x5 dari FAA. FAA risk matrix digunakan karena FAA sudah memiliki pengalaman yang baik pada masalah penerbangan. Standar risk matrix ini sudah diterapkan di seluruh bandara internasional di Amerika. Penerapan di bandara Soekarno Hatta diharapkan mampu memenuhi standar internasional. FAA merupakan badan sertifikasi yang setiap tahunnya melakukan safety audit di bandara maupun maskapai penerbangan. Dengan penerapan standar FAA risk matrix diharapkan bandara Internasional Soekarno Hatta mampu bersaing dengan bandara internasional lainnya dalam hal pengelolaan risiko. Kriteria skala mengacu pada FAA yaitu 1-5 sebagaimana Tabel 4.

Peristiwa risiko yang telah dinilai dipetakan kedalam risk matrix FAA dengan memasukkannya pada zona merah, kuning dan hijau sebagaimana Tabel 5. Semua risiko yang berada dalam zona merah mendapat perlakuan khusus yaitu berupa penanganan lebih lanjut. Semua risiko pada zona merah dicatat dalam daftar risiko potensial maka selanjutnya diurutkan berdasarkan RPN (kemungkinan kejadian $\mathrm{x}$ dampak) seperti ditunjukkan pada Tabel 6.

\section{Perancangan sistem pengendalian}

Sistem pengendalian dibuat untuk membantu manajer dalam mengambil keputusan. Sistem pengendalian berupa pencegahan terhadap peristiwa risiko yang belum terjadi dan penanganan risiko yang telah terjadi, mengacu kepada BowTie Model AS/NZS 4360 yang telah di rekomendasi oleh ISO 31000. Setiap pengendalian memiliki dinding-dinding pembatas (barrier) yang memiliki nilai kekuatan terhadap risiko. Setiap barrier memiliki penilaian sendiri terhadap kuat tidaknya pertahanan terhadap risiko. Ketujuh peristiwa risiko yang terdeteksi berbahaya kemudian dibuatkan dinding-dinding pengendalian berdasarkan pendapat sub-unit FRM. Berikut adalah sistem pengendalian yang dibuat untuk ketujuh jenis peristiwa risiko potensial yang telah terdeteksi.

\section{Permukaan runway pecah}

Beberapa penyebab permukaan runway pecah yaitu: meningkatnya jumlah traffic, menurunnya permukaan air tanah, dummy joint terlepas dan usia teknis. Beberapa upaya pencegahan pecahnya permukaan runway yaitu: pembuatan runway baru, pelarangan pemakaian air sumur disekitar area bandara, perawatan dan inspeksi dan sealant injection. Sedangkan pengendaliannya yaitu koordinasi dengan unit ATC untuk pengalihan traffic, meliputi airport liability insurance, overlay beton dan overlay hotmix.

\section{Kecelakaan pesawat saat take off/landing}

Beberapa penyebab risiko kecelakaan pesawat saat take off/landing yaitu: foreign object debris (FOD), runway incursion, bird strike, layang-layang dan standing water. Beberapa upaya pencegahan terjadinya risiko kecelakaan yaitu: pengawasan secara berkala, koordinasi unit terkait dan SOP perawatan fasilitas. Berdasarkan penyebab tersebut, pengendalian dilakukan dengan cara membuat laporan kronologis, koordinasi unit terkait, dan perbaikan fasilitas. 


\section{Terganggunya pelayanan navigasi dan komunikasi penerbangan}

Beberapa penyebab terganggunya pelayanan navigasi dan komunikasi penerbangan yaitu: fasilitas komunikasi melebihi idle time, pengadaan spare part yang memakan waktu lama, perusakan VSAT (very small aperture terminal)/stasiun penerima sinyal dari satelit dengan antena penerima dan terdapat interference frequence.

Beberapa upaya pencegahan yang diusulkan yaitu: merawat peralatan, memastikan spare part tersedia di gudang, memastikan SDM yang menangani kerusakan siap di lokasi, memperbaiki peralatan, dan perbaikan pada transceiver. Sedangkan pengendaliannya yaitu; memperbaiki peralatan, koordinasi dengan institusi terkait, dan menyusun contingency plan untuk penanganan gangguan komunikasi.

\section{Kecelakaan pesawat di area apron}

Beberapa penyebab kecelakaan pesawat di area apron yaitu: kompetensi petugas ground handling kurang memadai, petugas kurang tertib dalam menata fasilitas kerja setelah digunakan, miskomunikasi tentang pergerakan pesawat maupun kendaraan di area apron, jumlah petugas AMC terbatas, marking dan sign kurang jelas, fasilitas kendaraan ground handling kurang memadai, dan terbatasnya area Apron.

Beberapa upaya pencegahan terjadinya kecelakaan pesawat di area apron yaitu: pelatihan dan pendidikan bagi petugas di area apron, peningkatan inspeksi, penambahan jumlah personil, sosialisasi marking dan sign dengan petugas, pengecatan ulang marking dan sign, mengganti kendaraan dengan yang memadai, perawatan kendaraan, perluas area apron, dan pengaturan layout. Sedangkan pengendaliannya yaitu: investigasi kecelakaan, koordinasi dengan unit terkait, koordinasi dengan humas dan membuat laporan kronologis.

\section{Gangguan keamanan di bandara}

Beberapa penyebab gangguan keamanan di bandara yaitu: rusaknya pagar perimeter bandara, SOP penanganan keamanan kurang optimal dijalankan, jangkauan CCTV kurang memadai, fasilitas pengamanan (diantaranya: X-ray, WTMD, explosive detector) kurang memadai, layout pengamanan yang terbaru belum diketahui petugas, dan kompetensi petugas kurang memadai.

Beberapa upaya pencegahannya yaitu: peningkatan inspeksi di area pagar yang rusak, perbaikan fasilitas, evaluasi dan perbarui SOP, peningkatan inspeksi di area yang tak terjangkau CCTV, penambahan CCTV, membeli peralatan baru, kalibrasi peralatan, sosialisasi setiap ada layout baru, dan pelatihan dan pendidikan petugas. Sedangkan pengendaliannya yaitu dengan cara perbaikan fasilitas, membuat laporan kronologis, koordinasi dengan humas dan institusi terkait.

\section{Jetblast pesawat}

Beberapa penyebab yang dapat membuat jetblast pesawat yaitu: terlalu dekat jarak gedung dengan apron, menguji kekuatan power pesawat/ open full throttle di apron, dan melakukan run up sewaktu di apron. Beberapa upaya pencegahan terjadinya jetblast pesawat yaitu reposisi parking stand dan pembuatan notam idle powersaat pesawat taxing out. Sedangkan pengendaliannya yaitu membuat laporan kronologis, koordinasi dengan unit terkait, dan perbaikan fasilitas.

\section{Lolosnya barang berbahaya kedalam pesawat}

Beberapa penyebab yang membuat lolosnya barang berbahaya kedalam pesawat yaitu: teknologi $X$-ray tidak dapat mendeteksi barang berbahaya (DG), adanya pintu lain yang tidak terjaga, jumlah SDM AVSEC (aviation security) bersertifikat DG terbatas, pelatihan dan pendidikan petugas.

Beberapa upaya pencegahan lolosnya barang berbahaya kedalam pesawat yaitu: kalibrasi $X$ ray, pemeriksaan manual oleh petugas, membeli $X$-ray model terbaru, menempatkan personil, koordinasi barang melalui $X$-ray, penambahan jam kerja lembur, dan pemeriksaan $X$-ray satu per satu. Sedangkan pengendaliannya yaitu: koordinasi dengan humas, mengamankan barang 
berbahaya, membuat laporan kronologis, dan koordinasi dengan unit terkait.

Pengendalian hanya sampai tahap perencanaan dan tidak dilanjutkan kedalam tahap implementasi sehingga dinding-dinding pembatas (barrier) yang dirancang belum bisa diuji ketahanannya namun cukup baik untuk pengendalian risiko saat ini. Setiap pengendalian memiliki barrier yang memiliki nilai kekuatan terhadap risiko. Setiap barrier memiliki penilaian sendiri terhadap kuat atau tidaknya pertahanan terhadap risiko. Penelitian ini belum melibatkan penilaian pada sistem pengendalian, tetapi berakhir pada registrasi sistem pengendalian, karena penilaian tersebut dapat dilakukan bila sistem pengendalian sudah diterapkan dalam waktu yang cukup lama. Penelitian selanjutnya perlu dikembangkan hingga tahap implementasi sehingga dapat dilakukan penilaian pada sistem pengendalian.

\section{SIMPULAN}

Di Bandara Soekarno Hatta terdapat 7 peristiwa risiko yang mempunyai potensi bahaya yaitu: pecahnya permukaan runway, kecelakaan pesawat saat take off/landing, terganggunya pelayanan navigasi dan komunikasi penerbangan, kecelakaan pesawat di area apron, gangguan keamanan di bandara, jetblast pesawat, dan lolosnya barang berbahaya ke dalam pesawat. Upaya-upaya pencegahan terhadap ketujuh peristiwa risiko tersebut telah dilakukan dengan baik. Perancangan sistem pengendalian risiko juga sudah dibuat dengan baik, karena sudah divalidasi secara subjektif oleh kepala FRM, namun masih perlu dilakukan penilaian terhadap rancangan sistem pengendalian risiko yang ada.

\section{DAFTAR PUSTAKA}

Airmic, 2010. Structured Approach to Enterprise Risk Management (ERM) and The Requirements of ISO 31000, Alarm, IRM, The Public Risk Management Association, 6 Lloyd's Avenue, London EC3N 3AX.

U.S. Department of Transportation Federal Aviation Administration, 2009. Risk Management Handbook, diakses dari URL: https://www.faa. gov/ regulations_policies/handbooks_manuals/ aviation/risk_management_handbook/media/ risk_management_handbook.pdf, diakses 11 September 2013.

Abisay, T. G., 2011. Penilaian Risiko dan Perancangan Sistem Pengendalian Berbasis ISO 31000 Pada Fasilitas Operasi dan Teknik Bandara Soekarno Hatta, Tugas Sarjana, Fakultas Industri, Institut Teknologi Bandung, Bandung.

Harimurti, F., 2006. Manajemen Risiko, Fungsi dan Mekanismenya, Jurnal Ekonomi dan Kewirausahaan, Fakultas Ekonomi Universitas Slamet Riyadi Surakarta, 6 (1), 105 - 112.

Labombang, M., 2011. Manajemen Risiko Dalam Proyek Konstruksi, Jurnal SMARTek, 9 (1), 39-46

Nota, G., 2010. Advances in Risk Management, Sciyo, Croatia.

Sepang, B. A. W., Tjakra, J., Langi, J. E. Ch., dan Walangitan, D. R. O., 2013. Manajemen Risiko Keselamatan dan Kesehatan Kerja (K3) Pada Proyek Pembangunan Ruko Orlens Fashion Manado, Jurnal Sipil Statik, 1 (4), 282-288.

Yasa, I W. W, Dharma, I G. B. S., dan Sudipta, I.K., 2013. Manajemen Risiko Operasional dan Pemeliharaan Tempat Pembuangan Akhir (TPA) Regional Bangli di Kabupaten Bangli, Jurnal Spektran, 1 (2), 30-38. 